\title{
A Ceramic Sherd Assemblage from a Caddo Site in the Upper Neches River Basin, Henderson County, Texas
}

Timothy K. Perttula

Heritage Research Center, Stephen F. Austin State University

Follow this and additional works at: https://scholarworks.sfasu.edu/ita

Part of the American Material Culture Commons, Archaeological Anthropology Commons, Environmental Studies Commons, Other American Studies Commons, Other Arts and Humanities Commons, Other History of Art, Architecture, and Archaeology Commons, and the United States History Commons

Tell us how this article helped you.

This Article is brought to you for free and open access by the Center for Regional Heritage Research at SFA ScholarWorks. It has been accepted for inclusion in Index of Texas Archaeology: Open Access Gray Literature from the Lone Star State by an authorized editor of SFA ScholarWorks. For more information, please contact cdsscholarworks@sfasu.edu. 


\section{A Ceramic Sherd Assemblage from a Caddo Site in the Upper Neches River Basin, Henderson County, Texas}

\section{Creative Commons License}

\section{(c) (1) \&}

This work is licensed under a Creative Commons Attribution-NonCommercial 4.0 International License 


\title{
A Ceramic Sherd Assemblage from a Caddo Site in the Upper Neches River Basin, Henderson County, Texas
}

\author{
Timothy K. Perttula
}

\section{INTRODUCTION AND SITE LOCATION}

This article reports on a collection of ancestral Caddo artifacts from an unrecorded site in the upper Neches River basin in northeastern Henderson County in East Texas (Figure 1). The collection had been found by landowners on an unreported Caddo site in this locale-which appears to be in the Caddo Creek valley west of the Neches River - and the collection was recently relocated by Debbie Shelley of Frankston, Texas. Mrs. Shelley brought the collection to the 2015 East Texas Archeological Conference, and provided the opportunity to fully document the ceramic and lithic artifacts in the collection.

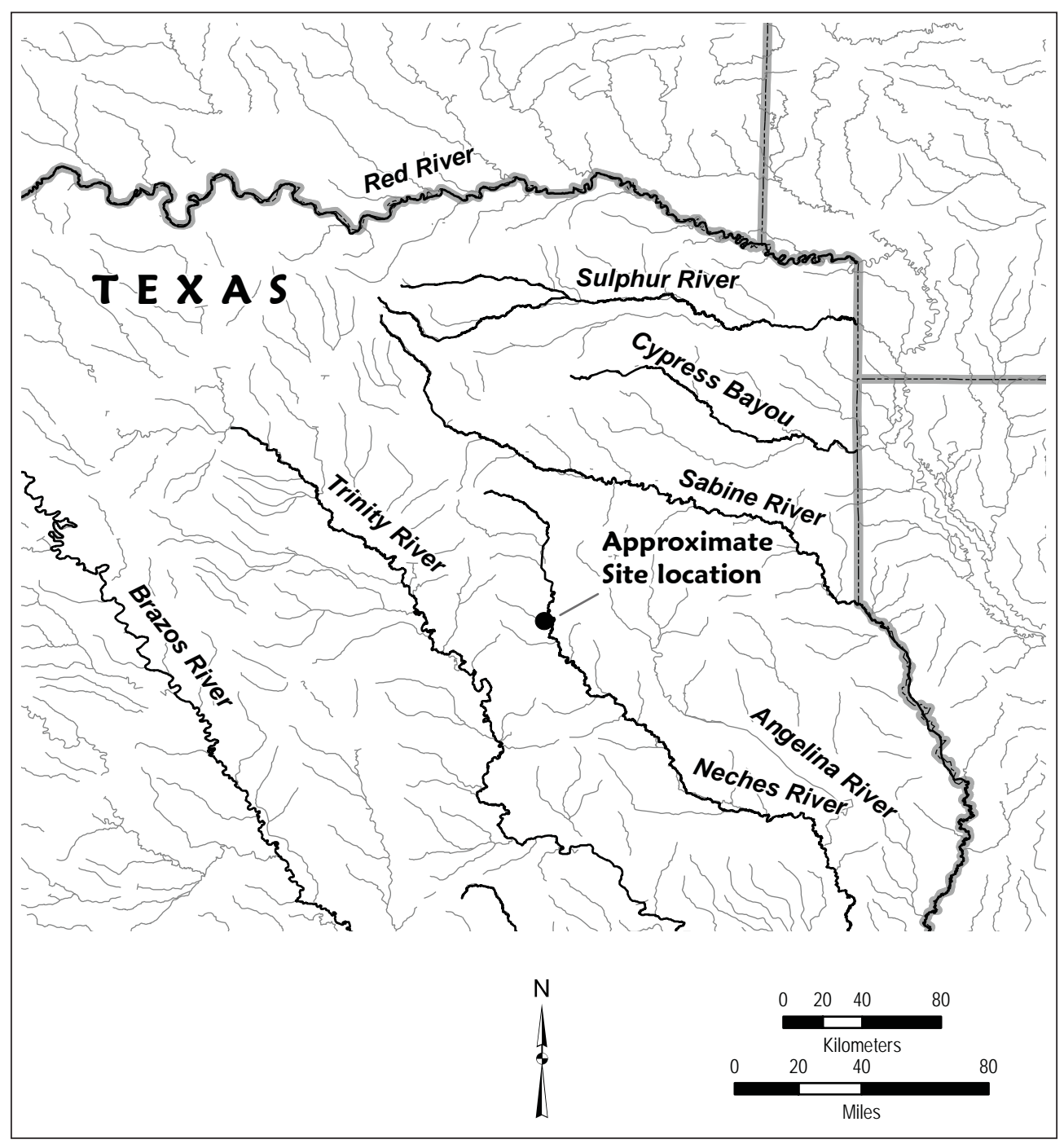

Figure 1. Approximate site location of the ancestral Caddo site in Henderson County in the upper Neches River basin in East Texas. 


\section{Ceramic Sherd Assemblage}

The collection contains 257 sherds from ancestral Caddo ceramic vessels (Table 1). The plain to decorated sherd ratio for the assemblage is 1.21 (141/116). As with other upper Neches River basin Caddo sites (see Perttula 2011a:301), the vast majority of the sherds are from grog-tempered vessels ( 94.4 percent) (i.e., crushed sherds used as temper), and only 5.4 percent of the sherds are from burned bone-tempered vessels. None of the fine ware sherds in the assemblage are from bone-tempered vessels.

Table 1. Ceramic sherd assemblage.

\begin{tabular}{lccc}
\hline Ware & Grog-tempered & Bone-tempered & $\mathrm{N}$ \\
\hline Plain & 133 & 8 & 141 \\
Utility & 85 & 6 & 91 \\
Fine & 25 & - & 25 \\
\hline Totals & 243 & 14 & 257 \\
\hline
\end{tabular}

The utility ware sherds are from vessels - most commonly cooking jars - with wet paste decorations; wet paste decorations are those that were applied to the vessel body while it was still wet and before the vessel was fired. About 78 percent of the decorated sherds are from utility ware vessels (see Table 1). In this assemblage, sherds from vessels decorated with brushing marks are most common, and they represent 36 percent of the utility ware sherds (Table 2). There are also sherds from vessels with both brushed and other decorative elements (i.e., incised, incised-punctated, and punctated); they comprise another 11 percent of the utility ware sherds. Sherds from vessels decorated with fingernail or tool punctations are also abundant (24 percent of the utility ware sherds). Sherds from incised vessels account for almost 20 percent of the utility ware sherds, and another 7.7 percent of the utility ware sherds have incised-punctated decorative elements. There is only one (1.1 percent) body sherd with appliqued-incised decorative elements (Table 2).

Table 2. Decorative methods and elements in the utility wares in the ceramic sherd assemblage.

Decorative method/ Rim Body N

Decorative element

Appliqued-Incised

appliqued node and adjacent straight line

\section{Brushed}

opposed brushing marks

overlapping brushing marks

parallel brushing marks

parallel brushed panels

\section{Brushed-Incised}

parallel brushed incised marks and lines

parallel brushing marks and overlying parallel incised lines

\section{Brushed-Incised-Punctated}

vertical brushing marks and overlying incised triangle filled with tool punctations [on rim], and overlying vertical incised lines [on body] 
Table 2. Decorative methods and elements in the utility wares in the ceramic sherd assemblage, cont.

\begin{tabular}{|c|c|c|c|}
\hline $\begin{array}{l}\text { Decorative method/ } \\
\text { Decorative element }\end{array}$ & Rim & Body & $\mathrm{N}$ \\
\hline \multicolumn{4}{|l|}{ Brushed-Punctated } \\
\hline $\begin{array}{l}\text { parallel brushed and adjacent fingernail } \\
\text { punctated rows }\end{array}$ & - & 1 & 1 \\
\hline \multicolumn{4}{|l|}{ Incised } \\
\hline cross-hatched lines & - & 1 & 1 \\
\hline diagonal lines & 1 & - & 1 \\
\hline diagonal opposed lines & 1 & 2 & 3 \\
\hline horizontal and cross-hatched lines & 1 & - & 1 \\
\hline horizontal and diagonal lines & 1 & - & 1 \\
\hline opposed lines & - & 2 & 2 \\
\hline parallel lines & - & 7 & 7 \\
\hline straight line & - & 2 & 2 \\
\hline \multicolumn{4}{|l|}{ Incised-Punctated } \\
\hline $\begin{array}{l}\text { diagonal and curvilinear incised zones with } \\
\text { tool punctations }\end{array}$ & 1 & - & 1 \\
\hline $\begin{array}{l}\text { diagonal opposed lines and triangular zone } \\
\text { filled with tool punctations }\end{array}$ & 1 & - & 1 \\
\hline $\begin{array}{l}\text { incised triangle element filled with linear } \\
\text { tool punctations }\end{array}$ & - & 2 & 2 \\
\hline $\begin{array}{l}\text { horizontal and vertical-oriented rows of finger- } \\
\text { nail punctations divided by single horizontal } \\
\text { line }\end{array}$ & - & 1 & 1 \\
\hline $\begin{array}{l}\text { straight incised line between two panels filled } \\
\text { with rows of tool punctations }\end{array}$ & - & 1 & 1 \\
\hline $\begin{array}{l}\text { straight incised line and adjacent row of tool } \\
\text { punctations }\end{array}$ & - & 1 & 1 \\
\hline \multicolumn{4}{|l|}{ Punctated } \\
\hline fingernail punctated rows & 2 & 11 & 13 \\
\hline linear tool punctated rows & - & 1 & 1 \\
\hline tool punctated rows & - & 8 & 8 \\
\hline Totals & 8 & 83 & 91 \\
\hline
\end{tabular}

The appliqued-incised sherd in the collection has a large appliqued node adjacent to a single straight incised line (see Table 2); it is likely that this is from a jar with a series of nodes around the rim, with diagonal incised lines between the nodes. The many brushed sherds in the assemblage are from Bullard Brushed vessels that have brushing marks (from drawing a clump of grass across the surface of the vessel when it was still wet) on the body of jars, and the brushed sherds include one with panels of fine parallel brushing marks, as well as sherds with the brushing oriented in opposed, overlapping, and parallel marks (see Table 2). The parallel brushed sherds were likely oriented vertically on the vessel body. The brushed-incised sherds have brushing marks adjacent to parallel incised lines, or the incised lines were laid down over the brushing marks (Figure 2a). One lower rim-upper body sherd was first decorated with vertical brushing marks, after which vertical incised lines were drawn on the vessel body, and a diagonal incised triangle element was drawn on the vessel rim (Figure 2b). Then, the incised triangle element was filled with rows of tool punctations. The 
one brushed-punctated sherd with rows of fingernail punctations adjacent to parallel brushing marks is also from a Bullard Brushed vessel.

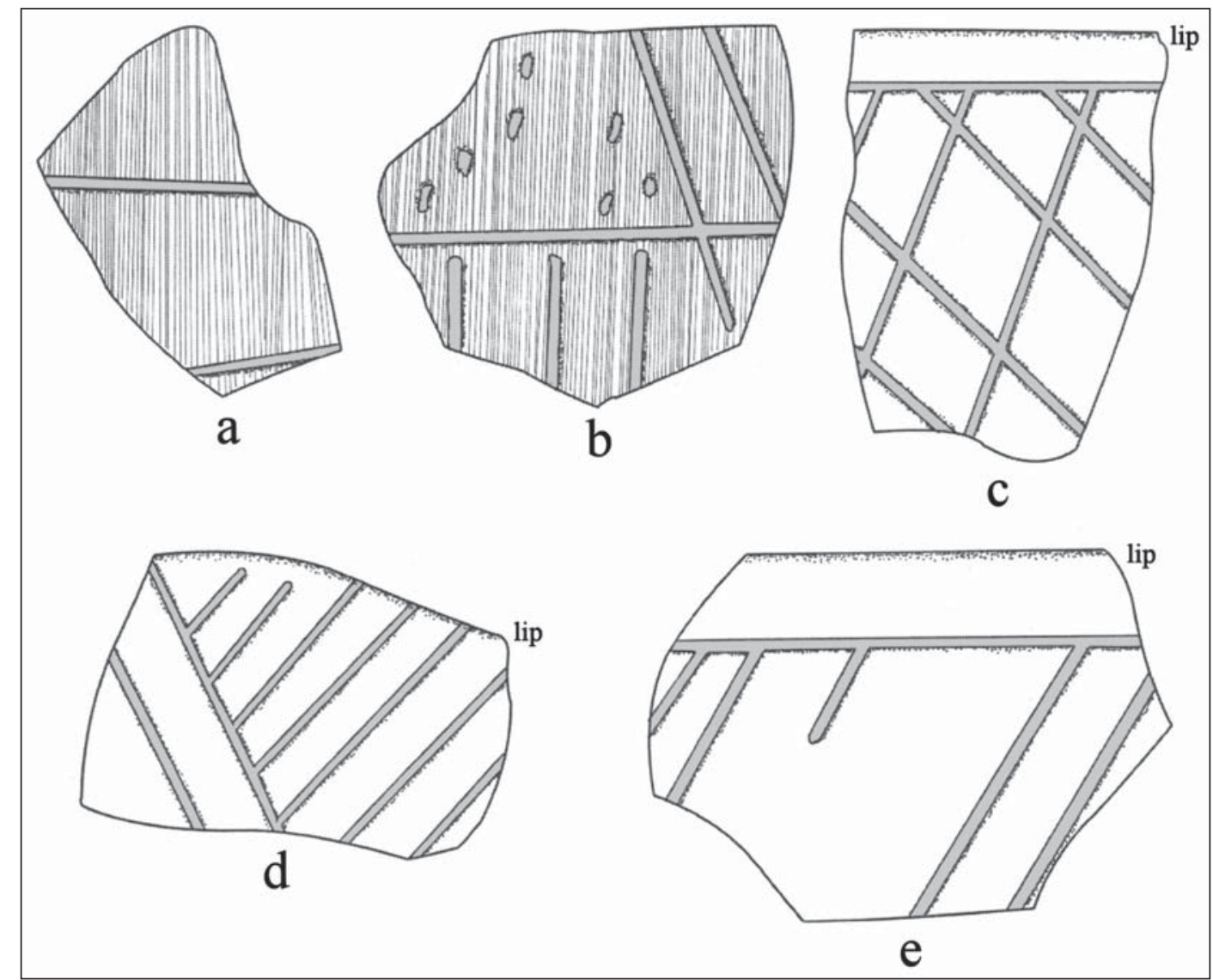

Figure 2. Selected brushed-incised, brushed-incised-punctated, and incised decorative elements on sherds in the ceramic assemblage; a, brushed-incised body sherd; $b$, brushed-incisedpunctated body sherd; c-e, incised rim sherds.

The sherds from incised vessels have cross-hatched, diagonal, and diagonal opposed decorative elements on the rims (see Figure 2c-e). These are common decorative elements on Maydelle Incised vessels found in the upper Neches River basin (see Suhm and Jelks 1962:Plate 52a-d, f). The incised-punctated rim and body sherds from the Henderson County site are also from Maydelle Incised vessels, and these feature "diagonals pitched in alternate directions with punctations filling the areas between them" (Suhm and Jelks 1962:103 and Plate 52e) (Figure 3a, c). One of the incised-punctated rims has diagonal and curvilinear incised zones filled with punctations (Figure 3b), and a body sherd has horizontal incised zones with rows of horizontal and vertically-oriented fingernail punctations (Figure 3d).

A number of the utility ware sherds in this Henderson County ceramic assemblage have either fingernail or tool punctated decorative elements (see Table 2). The two rims have rows of fingernail punctations (see Figure 3e).

The fine ware sherds from the site are from vessels with engraved (i.e., decorated after the vessel had been fired) decorative elements ( 80 percent) and red-slipping ( 20 percent) (Table 3$)$. Fifteen percent of the engraved sherds are from bottles, and the remainder appear to be from carinated bowls. 


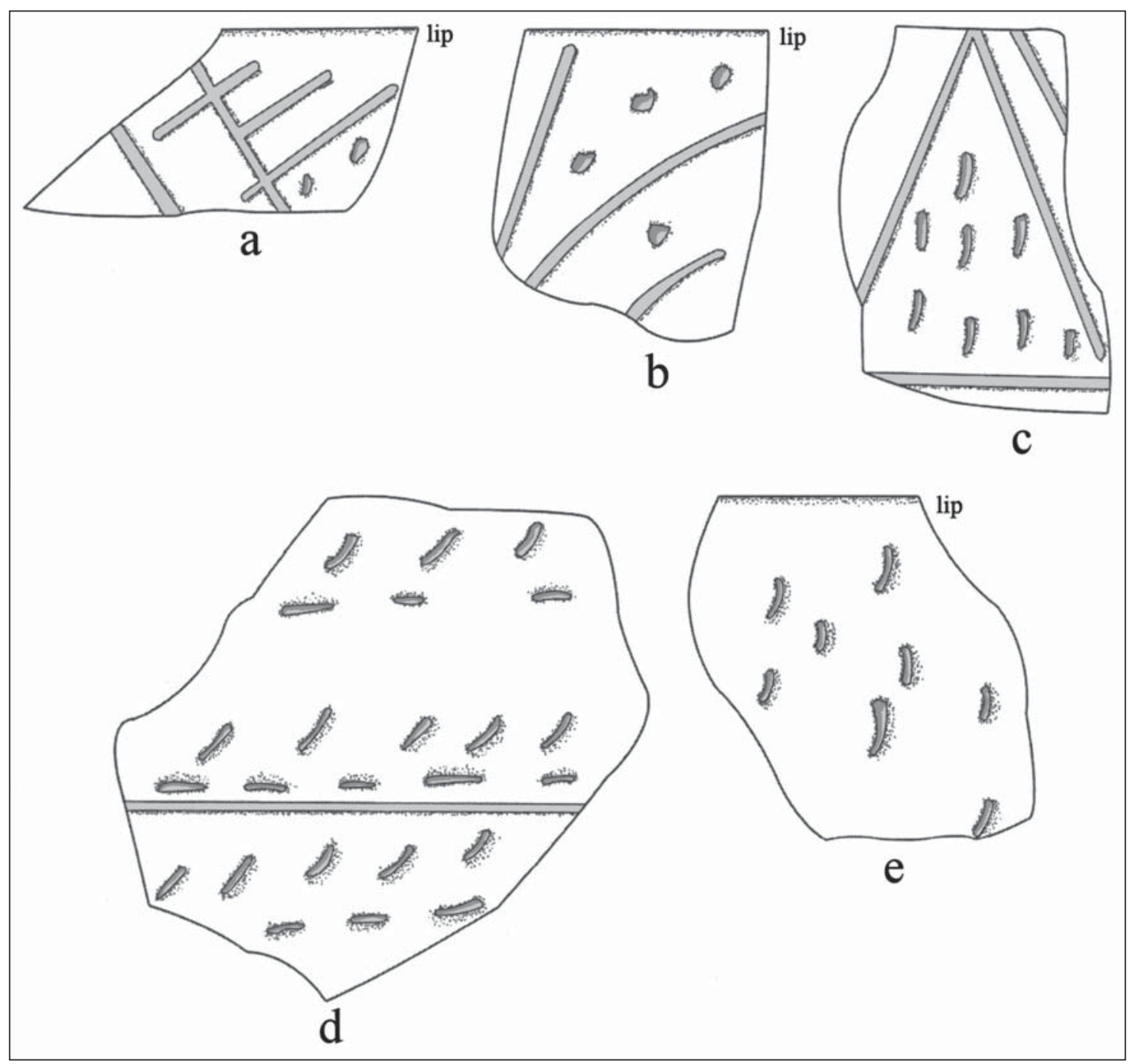

Figure 3. Selected incised-punctated and punctated decorative elements on sherds in the ceramic assemblage: $a-d$, incised punctated sherds; e, fingernail punctated rim sherd.

Table 3. Decorative methods and elements in the fine wares in the ceramic sherd assemblage.

\begin{tabular}{lccc}
\hline $\begin{array}{l}\text { Decorative method/ } \\
\text { Decorative element }\end{array}$ & Rim & Body & \\
\hline $\begin{array}{l}\text { Engraved } \\
\text { concentric semi-circles* }\end{array}$ & - & 1 & 1 \\
diagonal lines & 1 & - & 1 \\
diagonal opposed lines & 1 & - & 1 \\
diagonal-vertical lines & 1 & 4 & 1 \\
hatched zones* & - & 1 & 1 \\
hatched triangles on interior thickened rim & - & 1 & 1 \\
horizontal and curvilinear lines & - & - & 1 \\
horizontal, diagonal, and curvilinear lines & - & 3 & 1 \\
horizontal and diagonal opposed lines & 1 & 2 & 3 \\
closely spaced parallel lines* & - & 2
\end{tabular}


Table 3. Decorative methods and elements in the fine wares in the ceramic sherd assemblage, cont.

Decorative method/

$\operatorname{Rim}$

Body

$\mathrm{N}$

Decorative element

\section{Engraved Bottle Sherds}

horizontal and diagonal lines

parallel lines and curvilinear hatched zone*

straight line and triangular element

$\begin{array}{lll}- & 1 & 1 \\ - & 1 & 1 \\ - & 1 & 1\end{array}$

\section{Red-Slipped}

ext. red-slipped

int./ext. red-slipped

Totals

3
-
-

$-\quad 2$

4

21

*includes sherds that have a red pigment rubbed in the engraved lines

The engraved rim sherds have vertical panels filled with diagonal lines (Figure 4a), diagonal lines, and diagonal opposed lines (Figure 4b). An interior-thickened rim has a row of hatched triangles (Figure 4c), and is from a Spoonbill Engraved carinated bowl. Spoonbill Engraved was defined by Perttula et al. (2009) on the basis of several engraved bowls recovered from Middle Caddo period (ca. A.D. 1200-1400) sites in the upper Sabine River basin. These vessels have interior thickened rims with upper and lower sets of hatched (3-4 hatched lines) engraved triangles. The apex of the upper and lower rows of triangles usually touch (Perttula and Selden 2014:Figure 16).

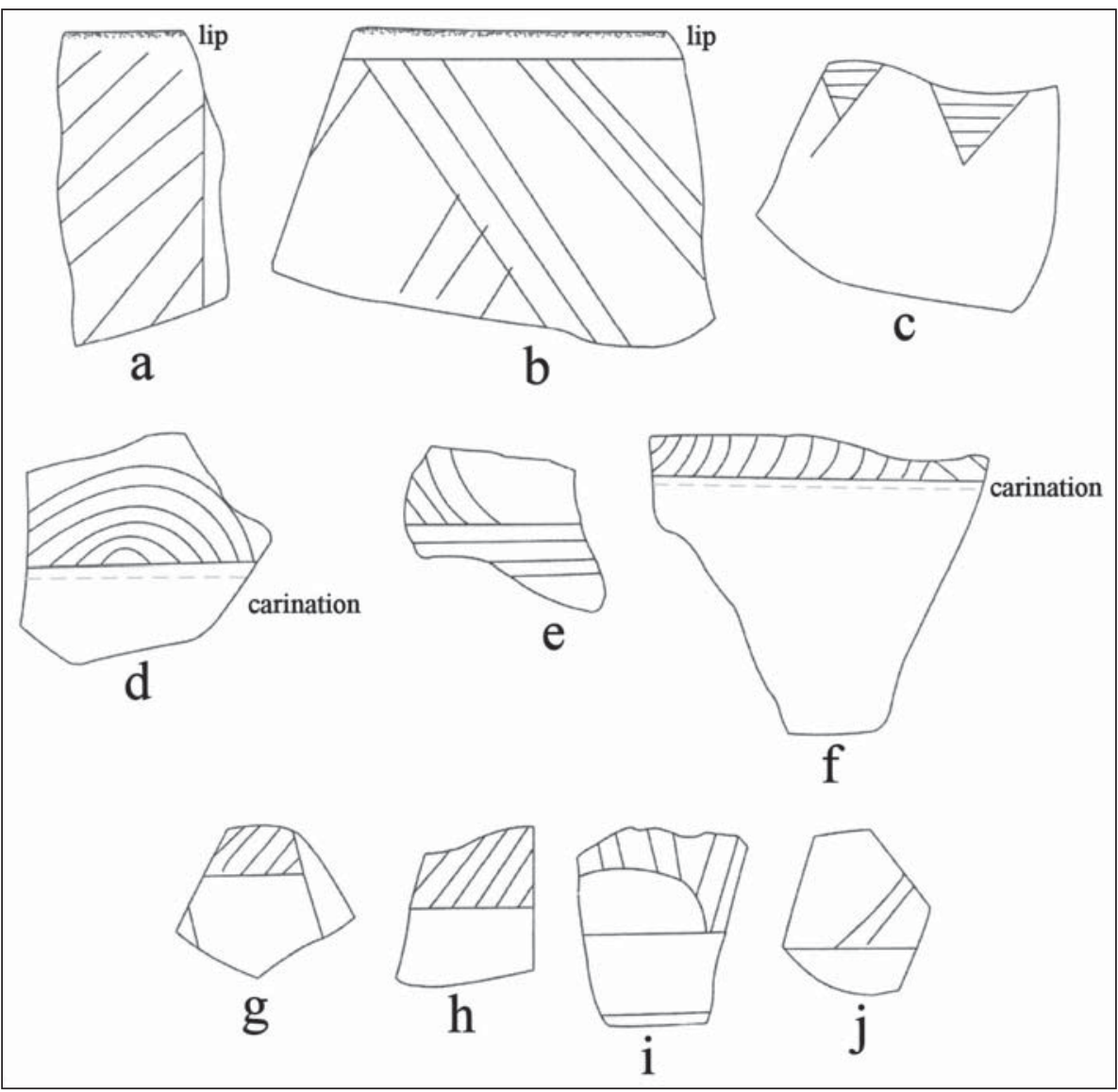

Figure 4. Selected engraved decorative elements on sherds in the ceramic assemblage: $\mathrm{a}-\mathrm{h}$, carinated bowl sherds; $\mathrm{i}-\mathrm{j}$, bottle sherds. 
There are three sherds in the assemblage that may be from early varieties of Poynor Engraved (i.e., found in other assemblages that date from ca. A.D. 1320-1480) (see Perttula 2011a:Figures 6-64 and 6-65). These have concentric semi-circles (see Figure 4d), horizontal and curvilinear lines (see Figure 4e), and horizontal-diagonal-and curvilinear lines above the vessel carination (see Figure 4f). Another group of four carinated bowl sherds have hatched engraved zones (see Figure $4 \mathrm{f}-\mathrm{g}$ ), and one bottle sherd has a curvilinear hatched zone (see Figure 4i). There is also a bottle sherd with horizontal and closely-spaced diagonal engraved lines on the vessel body (see Figure $4 \mathrm{j}$ ).

The use of a red, ochre-rich, clay pigment on engraved fine ware vessels was apparently common at this Henderson County site. Among the bottle sherds, 33 percent have a red pigment rubbed in the engraved design, and 22 percent of the sherds from engraved carinated bottles have a red pigment (see Table 3 ).

The frequency of red-slipped sherds among the fine wares in this site is notable (see Table 3); they also comprise 4.3 percent of all the decorated sherds from the site. Red-slipped vessels are generally far from common in upper Neches River basin Caddo sites. In a sample of 462 ceramic vessels from more than 30 upper Neches River basin Caddo sites in Anderson, Cherokee, Henderson, and Smith counties, only 0.3 percent of the vessels were red-slipped (Perttula 2011a:Table 6-35). In a large assemblage of decorated sherds $(n=2572)$ from the Lang Pasture site (41AN38), with components that date from ca. A.D. 1320-1480, only 0.7 percent were red-slipped (Perttula 2011a:Table 6-3).

\section{Ceramic Pipe Sherd}

The one grog-tempered ceramic pipe sherd in the collection from this northeastern Henderson County site is the base to an $\mathrm{L}$-shaped elbow pipe. It is $5.2 \mathrm{~mm}$ in diameter and $5.4 \mathrm{~mm}$ thick. The $\mathrm{L}-$-shaped elbow pipe is the earliest form of elbow pipe in the upper Neches River basin, and began to be manufactured by the Caddo in the region after ca. A.D. 1350 to as late as ca. A.D. 1480 (Perttula 2011a:215).

\section{Arrow point}

There is a single Early Caddo period (ca. A.D. 1000-1200) Catahoula arrow point in the collection. The unifacially flaked arrow point has an expanding stem, corner notching, and broad barbs; there are upwardpointing serrations on the blade. It is made from a gray chert and is $19.9 \mathrm{~mm}$ in length, $15.9 \mathrm{~mm}$ in width, is $3.3 \mathrm{~mm}$ in thickness, and has a $6.7 \mathrm{~mm}$ stem width.

\section{SUMMARY AND CONCLUSIONS}

The assemblage of ancestral Caddo artifacts - including ceramic sherds from broken ceramic vessels, an elbow pipe sherd, and a single arrow point - from this site in the upper Neches River basin in northeastern Henderson County suggest that they are the product of a domestic settlement or farmstead likely occupied primarily by a Caddo group belonging to a larger community of Caddo peoples for probably no more than one or two generations. The ceramic assemblage is comprised of sherds primarily from grog-tempered vessels, and almost 80 percent of the decorated sherds $(n=116)$ are from utility ware jars decorated with appliqued-incised, brushed, brushed-incised, brushed-incised-punctated, brushed-punctated, incised, incised-punctated, and punctated decorative elements; most of these sherds are from Bullard Brushed and Maydelle Incised vessels. The fine wares include sherds from engraved carinated bowls and bottles, among them a distinctive Spoonbill Engraved vessel sherd and a few early style Poynor Engraved sherds, along with red-slipped bowls and carinated bowls.

Other than the one Early Caddo period Catahoula arrow point, the ceramic sherd assemblage and the elbow pipe sherd would appear to be from an occupation that took place sometime between ca. A.D. 1350 1480. Various ceramic attributes and indices compiled from domestic Caddo sites in the upper Neches

River basin can be employed to reasonably establish when the site in northeastern Henderson County was 
principally occupied by Caddo peoples. These attributes and indices include such things as the styles of ceramic pipes that are present in the assemblage; as well as the percentage of brushed sherds in the decorated sherd samples from different sites; the percentage of bone temper in the assemblages; the percentage of wet-paste decorations other than brushing (i.e., incised, punctated, appliqued, neck-banded, etc.); the plain/decorated sherd ratio (P/DR); and the brushed sherd/wet paste decorated sherd ratio. The only ceramic pipe from the site is a form of elbow pipe that was in use between ca. A.D. 1350-1480 in this part of the Caddo area.

From the comparisons of the ceramic attribute data, six different groups of upper Neches River basin Caddo ceramic assemblages can be seriated (see O’Brien and Lyman 1999) from oldest (Group VI) to youngest (Group I). These groups seem to reflect temporal changes due to the high frequency of Late Caddo Frankston phase decorated types, such as Poynor Engraved, Maydelle Incised, Bullard Brushed, Hume Engraved, and engraved effigy vessels, that are found in the Groups II-IV sites (corresponding to the early, middle, and late parts of the Frankston phase) - as well as Patton Engraved sherds from sites in Group Iand the occurrence of Early and Middle Caddo types such as Canton Incised, Dunkin Incised, Holly Fine Engraved, and Pennington Punctated-Incised in the Group V and VI upper Neches River sites (Table 4).

Table 4. Comparative sherd assemblage data from selected upper Neches River basin Caddo sites.

\begin{tabular}{lllllll}
\hline Site & $\begin{array}{l}\text { No. of Dec. } \\
\text { Sherds }\end{array}$ & $\begin{array}{l}\% \\
\text { Brushed* }\end{array}$ & $\begin{array}{l}\text { \%bone- } \\
\text { temper }\end{array}$ & $\begin{array}{l}\text { \%Wet-paste } \\
\text { decorations }\end{array}$ & P/DR & $\begin{array}{l}\text { Brushed/Wet } \\
\text { paste ratio }\end{array}$
\end{tabular}

GROUP I (Allen phase, Historic Caddo, with Patton Engraved), ca. post-A.D. 1650

$\begin{array}{lllllll}\text { 41CE421 } & 1805 & 88.1 & ? & 8.6 & 0.30 & 9.10 \\ \text { Pine Snake } & 305 & 85.2 & 5.7 & 8.8 & 0.51 & 9.63 \\ \text { Blue Branch } & 49 & 84.0 & ? & 6.1 & 0.57 & 13.67 \\ 41 \text { CE354 } & 474 & 82.7 & 3.1 & 8.9 & 0.20 & 8.14\end{array}$

GROUP II (late Frankston phase), ca. A.D. 1560-1650

$\begin{array}{lllllll}\text { 41HE22 } & 228 & 85.5 & ? & 7.5 & 0.62 & 11.5 \\ \text { Henry } & & & & & \\ \text { Lake } & 188 & 81.9 & 3.2 & 7.3 & 0.48 & 11.0 \\ \text { Attaway } & 814 & 84.4 & ? & 10.6 & 1.71 & 8.0 \\ \text { Debro } & 311 & 80.0 & ? & 10.3 & 0.14 & 7.75 \\ \text { 41SM91 } & 179 & 82.7 & ? & 13.4 & 0.55 & 6.17 \\ \text { 41AN19 } & 5750 & 75.2 & 15.5^{* *} & 14.2 & 0.21 & 5.30 \\ \text { William } & & & & & & 0.44 \\ \text { Sherman } & 525 & 75.8 & ? & 16.2 & 4.68\end{array}$

GROUP III (middle Frankston phase), ca. A.D. 1480-1560

Forest

$\begin{array}{lllllll}\text { Drive } & 1693 & 68.6 & ? & 21.9 & 0.56 & 3.12 \\ \text { Halbert } & 1757 & 65.8 & 2.6 & 26.3 & 0.70 & 2.51 \\ \text { Woldert } & 1730 & 62.7 & 0.0 & 28.8 & 0.72 & 2.19 \\ \text { Ferguson/ } & 4116 & 60.8 & <1.0 & 27.9 & 0.61 & 2.17\end{array}$

Pipe

GROUP IV (early Frankston phase), ca. A.D. 1400-1480

$\begin{array}{lllllll}\text { 41AN38+ } & 1216 & 57.7 & ? & 26.1 & 1.28 & 2.21 \\ \text { Tomato } & & & & & & \\ \text { Patch } & 912 & 49.2 & ? & 41.7 & 1.50 & 1.21 \\ \text { 41SM88 } & 95 & 37.9 & ? & 49.5 & 1.53 & 1.31\end{array}$


Table 4. Comparative sherd assemblage data from selected upper Neches River basin Caddo sites, cont.

\begin{tabular}{|c|c|c|c|c|c|c|}
\hline Site & $\begin{array}{l}\text { No. of Dec. } \\
\text { Sherds }\end{array}$ & $\begin{array}{l}\% \\
\text { Brushed* }\end{array}$ & $\begin{array}{l}\text { \%bone- } \\
\text { temper }\end{array}$ & $\begin{array}{l}\text { \%Wet-paste } \\
\text { decorations }\end{array}$ & $\mathbf{P} / \mathbf{D R}$ & $\begin{array}{l}\text { Brushed/Wet } \\
\text { paste ratio }\end{array}$ \\
\hline $\begin{array}{l}\text { Henderson } \\
\text { Co. site }\end{array}$ & 116 & 37.1 & 5.4 & 41.4 & 1.21 & 0.90 \\
\hline \multicolumn{7}{|l|}{ Mitchell, } \\
\hline Area D & 54 & 32.1 & 0.0 & 33.3 & 1.37 & 1.50 \\
\hline 41HE337 & 149 & 35.6 & 5.6 & 45.6 & 2.25 & 0.78 \\
\hline \multicolumn{7}{|c|}{ GROUP V (Middle Caddo period), ca. A.D. 1200-1400 } \\
\hline 41AN38++ & 1356 & 22.3 & $?$ & 50.3 & 1.99 & 0.44 \\
\hline 41SM404 & 446 & 16.0 & 8.5 & 60.7 & 1.73 & 0.26 \\
\hline 41SM73 & 165 & 26.1 & $?$ & 72.7 & 2.61 & 0.37 \\
\hline \multicolumn{7}{|l|}{ White } \\
\hline Mule & 1404 & 18.5 & 1.5 & 63.7 & 2.61 & 0.29 \\
\hline 41HE139 & 40 & 17.5 & 8.1 & 65.0 & 2.51 & 0.33 \\
\hline \multicolumn{7}{|l|}{ Broadway, } \\
\hline $\mathrm{Z} 1 / 2$ & 256 & 10.9 & 28.8 & 70.0 & 3.97 & 0.16 \\
\hline \multicolumn{7}{|c|}{ GROUP VI (likely Early Caddo period), ca. pre-A.D. 1200} \\
\hline $\begin{array}{l}\text { Broadway, Z3 } \\
\text { Mitchell, }\end{array}$ & 155 & 9.7 & 32.3 & 73.5 & 3.80 & 0.13 \\
\hline Areas A-C & 56 & 1.3 & 12.0 & 65.7 & 1.71 & 0.03 \\
\hline 41SM87 & 36 & 0.0 & $?$ & 69.4 & 4.44 & 0.00 \\
\hline
\end{tabular}

Source: Perttula 2011b:Table 2

$\mathrm{P} / \mathrm{DR}=$ plain/decorated sherd ratio; $* \%$ brushed represents the percentage of brushed sherds among all the decorated sherds; + southern area; ++northern area; **based on the analysis of vessel batches, not a detailed analysis of all the sherds from the site (see Kleinschmidt 1982)

This particular seriation, focusing on the three different temporal groupings of Frankston phase sites and one group of Allen phase sites, is also supported by differences in: (a) the proportions of vessels of Poynor Engraved varieties, Patton Engraved, engraved effigy vessels, Maydelle Incised, La Rue Neck Banded, and Bullard Brushed in upper Neches River Caddo burials (see Perttula 2011a), (b) differences in the relative frequencies of common vessel forms in Poynor and Patton Engraved vessels (Kleinschmidt 1982:Figure 24), as well as (c) the occurrence of European trade goods. The Group I-IV Caddo sites are part of an upper Neches River cluster that represented a conglomeration of constituent groups (i.e., groups related by kinship and close interaction and cultural transmission of knowledge and practices) that shared a broadly similar socio-political organization through time and space (see Story and Creel 1982:30-34).

Based on this seriation, the northeastern Henderson County site discussed in this article most likely dates to the same time period as the Group IV assemblages, in the early part of the Frankston phase (see Table 4). This group of sites has been estimated to date between ca. A.D. 1400-1480 (Perttula 2011a).

\section{ACKNOWLEDGMENTS}

I would like to first thank Debbie Shelley of Frankston, Texas, for the opportunity to study the collection of artifacts from this northeastern Henderson County site. Lance Trask prepared the figures for this article. 


\section{REFERENCES CITED}

Kleinschmidt, U. K. W.

1982 Review and Analysis of the A. C. Saunders Site, 41AN19, Anderson County, Texas. Master's thesis, Department of Anthropology, The University of Texas at Austin.

O’Brien, M. J. and R. L. Lyman

1999 Seriation, Stratigraphy, and Index Fossils: The Backbone of Archaeological Dating. Kluwer Academic/ Plenum Publishers, New York.

Perttula, T. K.

2011a The Ceramic Artifacts from the Lang Pasture Site (41AN38) and the Place of the Site within an Upper Neches River Basin Caddo Ceramic Tradition. In Archeological Investigations at the Lang Pasture Site (41AN38) in the Upper Neches River Basin of East Texas, assembled and edited by T. K. Perttula, D. B. Kelley, and R. A. Ricklis, pp. 145-320. Archeological Studies Program Report No. 129, Texas Department of Transportation, Environmental Affairs Division, Austin.

2011b The Pipe Site, a Late Caddo Site at Lake Palestine in Anderson County, Texas. Journal of Northeast Texas Archaeology 35:47-80.

Perttula, T. K. and R. Z. Selden Jr.

2014 Ancestral Caddo Ceramics in East Texas. Journal of Northeast Texas Archaeology 48:9-58.

Perttula, T. K., M. Walters, S. Marceaux, and B. Nelson

2009 Caddo Pottery Vessels and Pipes from Sites in the Middle and Upper Sabine and Upper Neches River Basins, Smith and Wood Counties, Texas. Special Publication No. 7. Friends of Northeast Texas Archaeology, Pittsburg and Austin.

Story, D. A. and D. G. Creel

1982 The Cultural Setting. In The Deshazo Site, Nacogdoches County, Texas, Vol. 1, edited by D. A. Story, pp. 20-34. Texas Antiquities Permit Series No. 7. Texas Antiquities Committee, Austin.

Suhm, D. A. and E. B. Jelks (editors)

1962 Handbook of Texas Archaeology: Type Descrptions. Special Publication No. 1, Texas Archeological Society, and Bulletin No. 4, Texas Memorial Museum, Austin. Reprinted in 2009, Gustav's Library, Davenport, Iowa. 